\title{
Diversity of macrobenthic community in the Negombo estuary, Sri Lanka with special reference to environmental conditions
}

\author{
D.D.G.L. DAHANAY AKA* AND M.J.S. WIJEY ARA TNE \\ Department of Zoology, University of Kelaniya, Kelaniya, Sri Lanka \\ *Corresponding author (Present address: National Aquatic Resources \\ Research and Development Agency, Crow Island, Colombo 15, Sri \\ Lanka, E-mail: gihan@nara.ac.lk)
}

\begin{abstract}
Benthic animals are generally considered to be good indicators of environmental conditions of aquatic ecosystems. The present study was undertaken to study the spatial variation of macrobenthic community in Negombo estuary $\left(7^{0} 6^{\prime}-7^{0} 12^{\prime} \mathrm{N} ; 79^{0} 49^{\prime}-79^{0} 53^{\prime} \mathrm{E}\right)$, which is subjected to a variety of anthropogenic activities. Benthic samples were obtained from 25 randomly selected sites in Negombo estuary in March 2003 and the macrobenthos were separated by wet sieving and identified as much as possible. The diversity of macrobenthos was determined using ShannonWiener index and the similarities among the macrobenthic communities at different sites were determined using Bray-Curtis similarity coefficient. Seventy-six species of benthic invertebrates belonging to 41 families were recorded during the study. Of the gastropods, those belonging to families Assimineidae, Cerithiidae, Haminoeidae and Hydrobiidae were the most abundant. The most abundant polychaete families were Pilargidiidae and Heterospionidae. Among amphipods, aorids were recorded in most of the sampling sites. The sampling sites were separated into several clusters based on the diversity of macrobenthos. The major environmental factors that influenced the separation of these clusters appeared to be salinity, presence of mangroves and soil texture.
\end{abstract}




\section{Introduction}

Benthic macrofauna plays an important role in aquatic ecosystems as primary and secondary consumers. Benthic invertebrates, specially benthic worms, are very important as a food resource for a large number of predators including commercially important benthic fish and as primary material exchangers across sediment-water interface (Popchenko 1971; Bouguenec \& Gaini 1989). Survival, distribution and abundance of macrobenthos depend on the characteristics of their environment such as salinity, organic mater content, soil texture, sediment particles and the ability to construct permanent burrows in the substratum (Perkins 1974).

Estuarine areas have long been subjected to industrialization and urbanization. The response by benthos to natural and anthropogenic perturbations is especially important because of their ability to integrate over time with changes to the water column and sedimentary regime (Elliott \& Taylor 1989). Published research on diversity indices of benthic communities and use of macrobenthos, as indicator organisms of environmental conditions are rare in Sri Lanka. Costa et al. (1997) have studied the abundance of oligochaetes in Colombo Lake, Sri Lanka in relation to environmental parameters. Gamlath and Wijeyaratne (1997) have identified gastropod and oligochaete species indicative of environmental condition in a lotic water body in Sri Lanka. Weerasundara et al. $(1999,2000)$ have related the species composition and densities of oligochaetes to environmental parameters in some fresh water lakes in Sri Lanka. Pathiratne and Weerasundara (2004) have used benthic oligochaetes for bioassessment of inland water bodies in Sri Lanka. However, there is no published research on the diversity of macrobenthos in brackish water environments of Sri Lanka in relation to environmental conditions. Therefore, the present study was carried out to investigate the spatial variation of macrobenthic diversity in the Negombo estuary, which is subjected to variety of anthropogenic activities (Samarakoon \& van Zon, 1991). An attempt was also made to find out how their distribution is affected by anthropogenic activities.

\section{Materials and Methods}

Benthic samples were collected from 25 randomly selected sites in the Negombo estuary (Fig. 1) in March 2003 using a Peterson grab and immediately fixed using $1 \%$ Rose Bengal. The approximate surface area sampled at each sampling site was $250 \mathrm{~cm}^{2}$. At each sampling site, the depth and salinity were measured and the presence of sea grasses and mangroves was recorded. The anthropogenic activities that are carried out at each sampling site such as disposal of sewage and fishing were also noted. The benthic samples were subjected to wet sieving through $4 \mathrm{~mm}, 2 \mathrm{~mm}, 1 \mathrm{~mm}$ and $500 \mu \mathrm{m}$ mesh sieves to separate the benthic fauna from the substrate 
(Sutherland 1997). The organisms retained in each sieve were collected, preserved in $10 \%$ formalin and identified as much as possible using Needham \& Needham (1962), Fauchald (1977), Kirthisinghe (1978), Fernando (1990) and Robertson et al. (1997). The number of organisms of each species was also recorded. The organic matter content of the benthic sediments at each site was determined using the method described by Williams (2001). Soil texture was determined as the approximate proportions of sand, silt and clay, using the method described by Brady and Weil (1999).

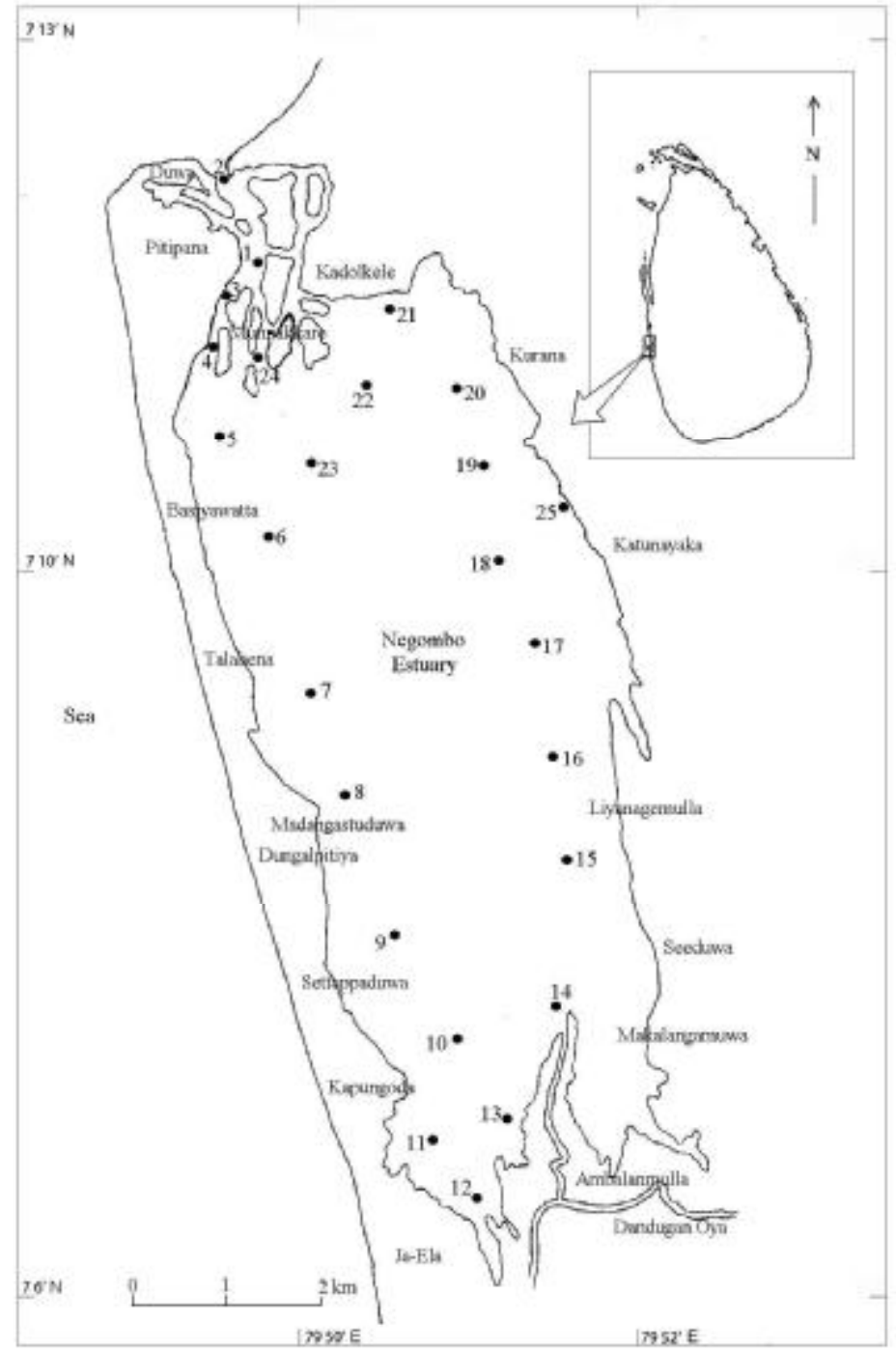

Fig.1. Map of the Negombo estuary showing sampling sites 
The diversity of macrobenthos in each site was estimated using Shannon-Wiener index (H') (Zar 1984; Krebs 1999) and the similarities of benthic communities among sampling sites were determined using BrayCurtis similarity coefficient (Bray \& Curtis 1957). In this analysis, the $4^{\mathrm{h}}$ root transformation was used to increase the influence by rare species. Ordinations of Non-metric Multidimensional Scaling (MDS) of sampling sites were determined based on the Bray-Curtis similarity matrix (Clarke \& Warwick 2001) using PRIMER-5 software package (V ersion 5.2.2). The BIO-ENV function in PRIMER-5 package was used to relate the multivariate community structure to environmental variables and to determine the most responsible variables for the inter-site variability of the benthic community.

\section{Results}

Seventy-six species of invertebrates belonging to 41 families were recorded in the benthic samples during the present study. Among them were 23 species of polychaetes, 24 species of gastropods, 16 species of bivalves and 13 species of crustaceans (Tables 1-3). Assimineids, Cerithiids, Haminoeids and Hydrobiids were the most abundant gastropods while Pilargidiids and Heterospionids were the most abundant polychaetes. Among amphipods, Aorids were the most abundant.

The highest number of species, which was 28 , was recorded at the sampling site 23 while no macrobenthos were recorded at the sampling site 25 . High values for species richness, which were above 20 , were recorded for sampling sites 2, 6, 7, 20, 22 and 23 (Table 4). The sampling site 2 was located at the sea mouth and the others were located in the northern part of the basin segment of the estuary. The lowest values for species richness, which were less than 10 , were recorded at sampling sites $4,12,14$ and 21. Of these, sampling sites 12 and 14 were located close to freshwater inlets of the estuary while site 21 was located in an area where water circulation is poor. However, the sampling site 4 was located in the canal segment of the estuary.

The high values for species diversity, which were above 2.50 were recorded at sampling sites $2,6,7,16,17,18,20$ and 23 (Table 4). Of these, the sampling sites other than the site 2 were located in the mid basin part of the estuary. The low values for species diversity were recorded at sampling sites $4,12,13,14$ and 15 (Table 4). The sites 12-15 were located in the southern part of the estuary close to freshwater inlets (Fig. 1). Sampling site 4 as indicated earlier is located in the canal segment of the estuary. 
Table 1. Abundance of different species of polychaetes recorded at each sampling site of Negombo estuary in March 2003

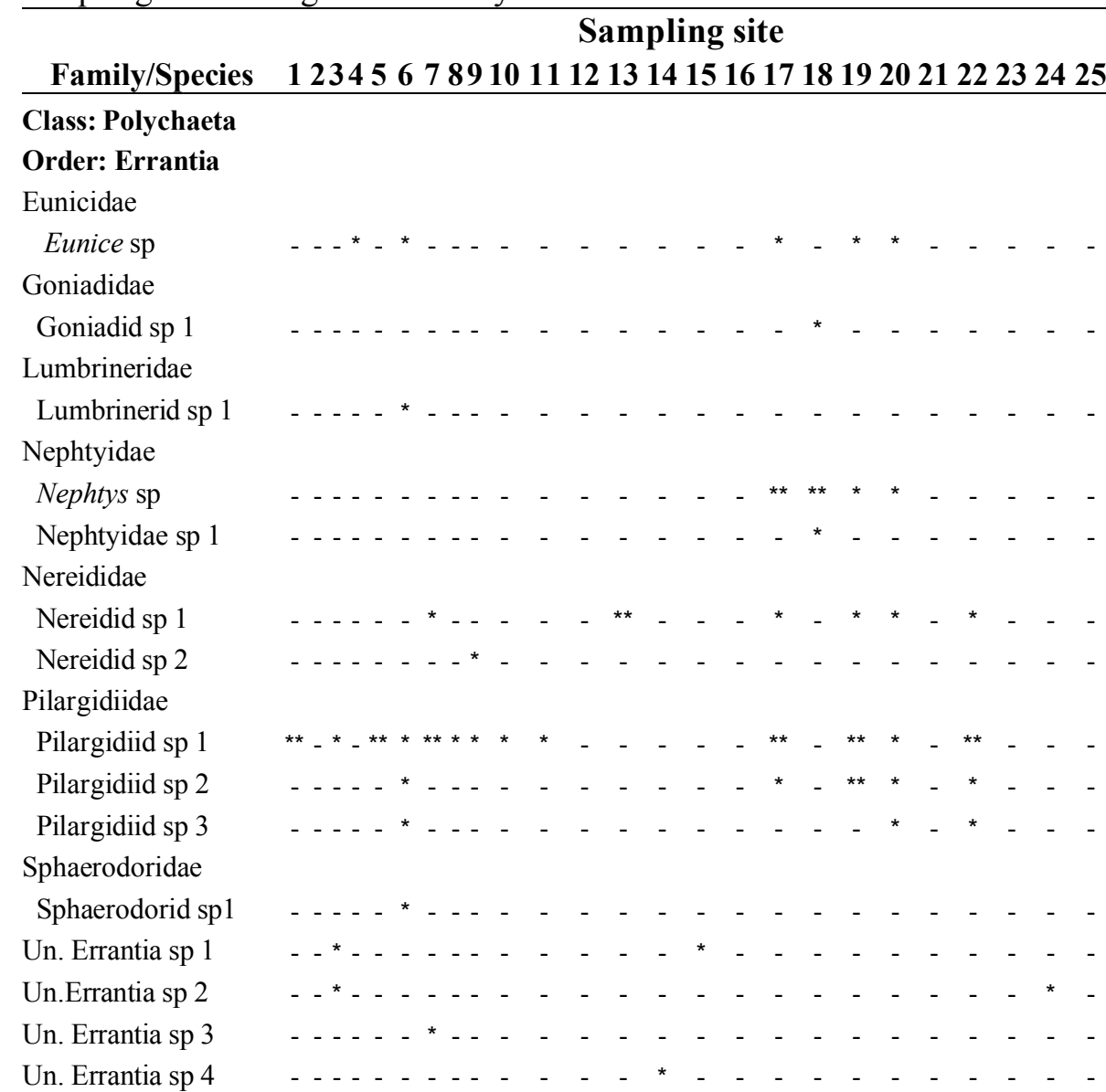

\section{Order: Sedentaria}

Heterospionidae

Heterospionid sp 1

Sabellariidae

Sabellariid sp 1

Sabellidae

Sabellid sp 1

Spionidae

Spionid sp 1

Syllidae

Syllid sp 1

Un.Sedenteria sp 1

Un.Sedenteria sp 2

Un.Sedenteria sp 3

${ }^{*}$ Less than 100 individuals $\mathrm{m}^{-2}$ ** 100 to 1000 individuals $\mathrm{m}^{-2}$ ${ }^{* * *}$ above 1000 individuals $\mathrm{m}^{-2,} \quad$ - Absence Un.- Unidentified Species 
Table 2. Abundance of different species of crustaceans recorded at each sampling site of Negombo estuary in March 2003.

Sampling site

Family/Species 12345678910111213141516171819202122232425

\section{Class: Crustacea}

Order: Amphipoda

Ampeliscidae

Ampeliscid sp 1

Aoridae

Aorid sp 1

Aorid sp 2

Gammaridae

Gammarid sp 1

Gammarid sp 2

Gammarid sp 3

Order: Isopoda

Cirolanidae

Cirolanid sp 1

Order: Decapoda

Atyidae

Caridina sp

Coenobitidae

Eupagurus sp

Penaeidae

Penaeus sp

\section{Other Crustaceans}

Balanidae

\section{Balanus sp}

Un. Crustacean sp 1

Un.Crustacean sp 2

* Less than 100 individuals $\mathrm{m}^{-2} \quad$ ** 100 to 1000 individuals $\mathrm{m}^{-2}$

*** above 1000 individuals $\mathrm{m}^{-2}$, - Absence Un.- Unidentified Species 
Table 3. Abundance of different species of gastropods and bivalves recorded at each sampling site of Negombo estuary in March 2003.

\section{Sampling site}

Family/Species 12345678910111213141516171819202122232425

\section{Class: Gastropoda}

Acmaeidae

Acmaeid sp 1

Assimineidae

Assimineid sp 1

Cerithiidae

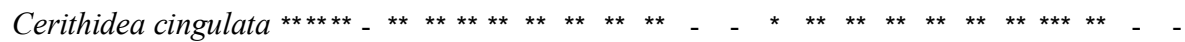

Dentaliidae

Dentalium sp

Haminoeidae

Haminoeid sp 1

Haminoeid sp 2

Haminoeid sp 3

Hydrobiidae

Hydrobiid sp 1

Hydrobiid sp 2

Littorinidae

Littorinid sp 1

Nassariidae

Nassariid sp 1

Naticidae

Naticid sp 1

Naticid sp 2

Naticid sp 3

Neritidae

Neritid sp 1

Planorbidae

Planorbid sp 1

Potamididae

Terebralia palustris

Terebridae

Terebrid sp 1

Thiaridae

Faunus ater

Thiarid sp 1

Thiarid sp 2

Un.Gastropod sp 1

Un.Gastropod sp 2

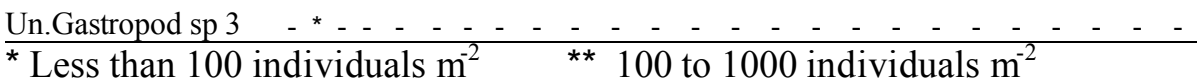

*** above 1000 individuals $\mathrm{m}^{-2}$ - Absence Un.- Unidentified Species 
Table 3. Continued

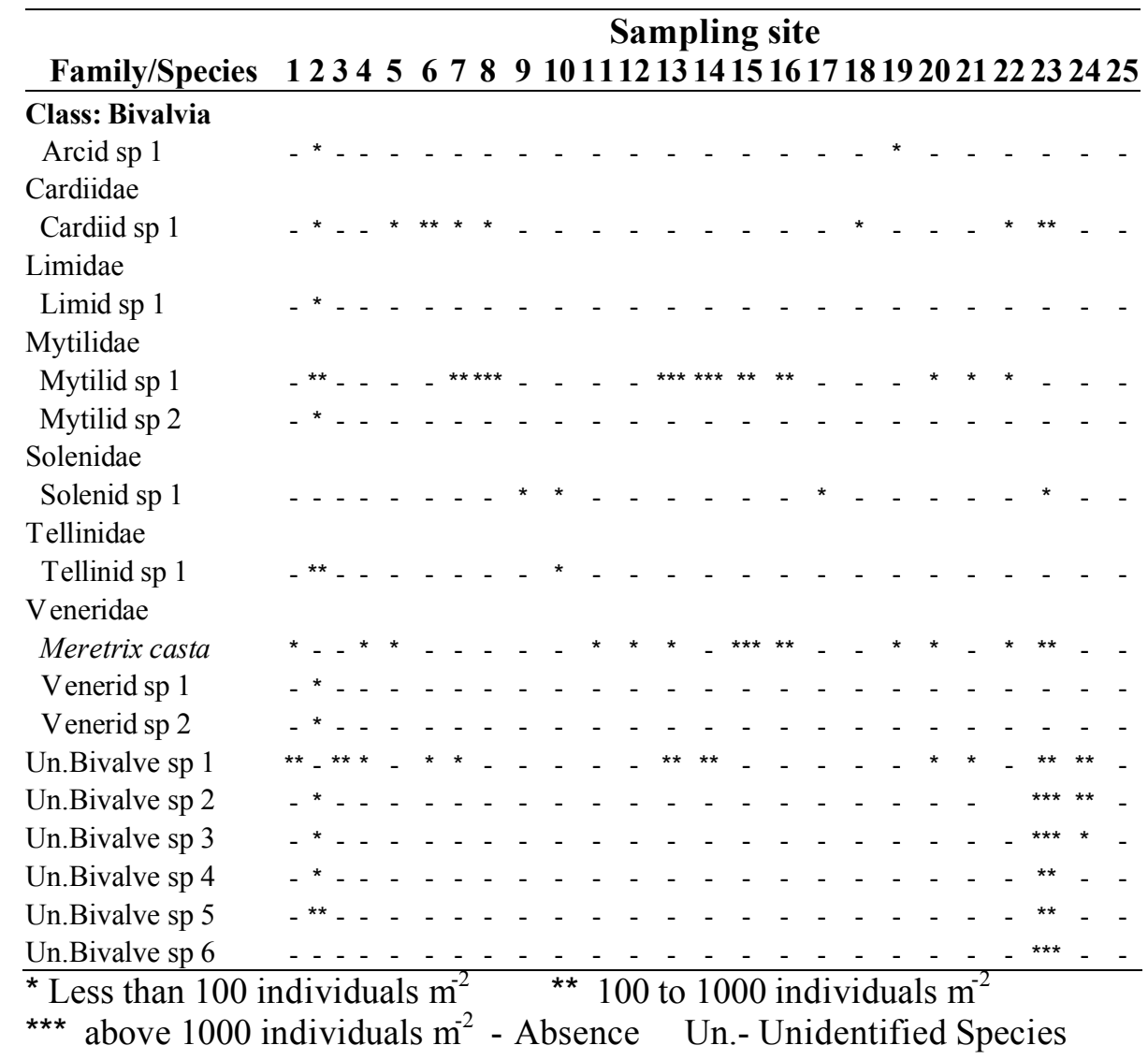

The values for the physico-chemical parameters of water and sediments at different sampling sites are given in Table 5. Salinity of water ranged from 8 to $30 \mathrm{~g} \mathrm{~kg}^{-1}$ and the water depth ranged from $0.5 \mathrm{~m}$ to $2 \mathrm{~m}$. The maximum depth and the maximum salinity were recorded at the mouth of the estuary (Site 2). As expected, the salinity was high in the northern part of the estuary, which is close to the sea mouth, and low in the southern part where the freshwater inflow takes place. The organic matter content of the bottom sediments ranged from 0.8 to $12 \%$, the sand content from 0 to $98 \%$ and the silt content from 0 to $98 \%$. The organic matter content in the bottom sediments was high at sampling sites 10,11 and 12, which were located in the southern part of the estuary. High silt contents in the bottom sediments were recorded at sampling sites 8, 9, 10 and 12, where no sand was recorded (Table 5). These sites were located in the southwestern part of basin segment of the estuary. No silt was recorded in the sampling sites located near the sea mouth and the mouth of the main canal (sites $2 \& 24)$. The clay content was always $<12.8 \%$ and in many sites, it was $<5 \%$. 
Table 4. Shannon - Wiener index ( $\left.\mathrm{H}^{\prime}\right)$ and species richness of macrobenthic invertebrates recorded at dfferent sampling sites of Negombo estuary.

\begin{tabular}{|c|c|c|}
\hline $\begin{array}{c}\text { Sampling } \\
\text { site }\end{array}$ & $\mathbf{H}^{\prime}$ & $\begin{array}{l}\text { Species } \\
\text { richness }\end{array}$ \\
\hline 1 & 2.11 & 10 \\
\hline 2 & 3.72 & 26 \\
\hline 3 & 2.24 & 13 \\
\hline 4 & 1.42 & 8 \\
\hline 5 & 2.36 & 14 \\
\hline 6 & 2.62 & 24 \\
\hline 7 & 2.87 & 22 \\
\hline 8 & 2.15 & 15 \\
\hline 9 & 2.43 & 13 \\
\hline 10 & 2.38 & 14 \\
\hline 11 & 2.35 & 13 \\
\hline 12 & 1.39 & 8 \\
\hline 13 & 1.92 & 13 \\
\hline 14 & 1.20 & 8 \\
\hline 15 & 1.55 & 11 \\
\hline 16 & 2.76 & 18 \\
\hline 17 & 3.33 & 19 \\
\hline 18 & 2.63 & 16 \\
\hline 19 & 2.48 & 14 \\
\hline 20 & 3.05 & 22 \\
\hline 21 & 2.37 & 9 \\
\hline 22 & 2.29 & 20 \\
\hline 23 & 3.20 & 28 \\
\hline 24 & 2.05 & 14 \\
\hline 25 & 0.00 & 0 \\
\hline
\end{tabular}

The sea grasses showed a patchy distribution in the estuary and these were abundant at sampling sites 5, 13, 14, 16, 19, 21 and 23. Mangroves were abundant at sampling sites 13,14 and 24 (Table 6). Brush piles were found near all sampling sites except for sites 2 and 4 and those located in the southern part of the estuary. Encircling nets are operated in the areas of the sampling sites 6,9-11,17-20, 22 and 23. No operation of encircling nets was observed in the southeastern part of the estuary. In the canal segment also, encircling nets are not operated. Disposal of sewage was noted at the sampling sites $1,3,7,8,12,16,18-20$ and 25 . 
Table 5. Physico-chemical parameters of water and sediments at different sampling sites of Negombo estuary in March 2003.

\begin{tabular}{|c|c|c|c|c|c|c|}
\hline \multirow{2}{*}{$\begin{array}{l}\text { Sampling } \\
\text { site }\end{array}$} & \multirow{2}{*}{$\begin{array}{l}\text { Depth } \\
(\mathrm{cm})\end{array}$} & \multirow{2}{*}{$\begin{array}{l}\text { Salinity } \\
\left(\mathrm{g} \mathrm{kg}^{-1}\right)\end{array}$} & \multirow{2}{*}{$\begin{array}{c}\text { Organic } \\
\text { matter } \\
\text { content }(\%)\end{array}$} & \multicolumn{3}{|c|}{ Soil Texture } \\
\hline & & & & Sand (\%) & Silt (\%) & Clay $(\%)$ \\
\hline 1 & 42.0 & 29 & 3.08 & 82.6 & 13.0 & 4.3 \\
\hline 2 & 197.0 & 30 & 0.78 & 97.7 & 0.0 & 2.3 \\
\hline 3 & 47.0 & 29 & 3.03 & 83.3 & 12.5 & 4.2 \\
\hline 4 & 46.0 & 28 & 1.65 & 85.0 & 10.0 & 5.0 \\
\hline 5 & 97.0 & 26 & 4.48 & 71.4 & 23.8 & 4.8 \\
\hline 6 & 128.0 & 24 & 2.24 & 87.0 & 8.7 & 4.3 \\
\hline 7 & 69.0 & 24 & 1.58 & 76.9 & 20.5 & 2.6 \\
\hline 8 & 61.5 & 17 & 2.04 & 0.0 & 98.4 & 1.6 \\
\hline 9 & 128.0 & 10 & 7.75 & 0.0 & 96.4 & 3.6 \\
\hline 10 & 125.5 & 10 & 11.92 & 0.0 & 97.9 & 2.1 \\
\hline 11 & 123.0 & 10 & 8.17 & 58.3 & 37.5 & 4.2 \\
\hline 12 & 105.0 & 8 & 11.41 & 0.0 & 97.3 & 2.7 \\
\hline 13 & 64.0 & 10 & 1.47 & 62.5 & 33.3 & 4.2 \\
\hline 14 & 89.5 & 8 & 1.91 & 70.2 & 28.1 & 1.8 \\
\hline 15 & 112.5 & 16 & 3.93 & 58.6 & 32.8 & 8.6 \\
\hline 16 & 89.5 & 14 & 3.76 & 59.0 & 31.1 & 9.8 \\
\hline 17 & 151.0 & 19 & 6.77 & 59.1 & 36.4 & 4.5 \\
\hline 18 & 184.5 & 24 & 4.65 & 51.1 & 36.2 & 12.8 \\
\hline 19 & 171.5 & 23 & 1.67 & 77.6 & 12.2 & 10.2 \\
\hline 20 & 115.0 & 25 & 2.06 & 79.4 & 17.6 & 2.9 \\
\hline 21 & 105.0 & 27 & 2.19 & 69.6 & 21.7 & 8.7 \\
\hline 22 & 123.0 & 26 & 2.97 & 65.2 & 32.6 & 2.2 \\
\hline 23 & 110.0 & 28 & 3.27 & 72.0 & 16.0 & 12.0 \\
\hline 24 & 151.0 & 30 & 0.96 & 95.5 & 0.0 & 4.5 \\
\hline 25 & 92.0 & 24 & 1.27 & 67.3 & 28.8 & 3.8 \\
\hline
\end{tabular}

The results of the present study indicated that a gammarid species was the most abundant in the sample sites, which are closer to the human dwellings (Table 2). This species was less abundant in other areas of the estuary. However, this species could not be identified to species level due to unavailability of keys. Further, the gastropods, which were abundant in other areas, were not found at these sites. At the sample site closer to the fiber mill (Site 8), the abundance of mytilids was high. In the sample site closer to the effluent discharge point of the shrimp farm, the species richness as well as the abundance of polychaetes, gastropods and bivalves were low. Further, the amphipods and isopods, which were abundant in other parts of the estuary, were absent at this site. 
Table 6. The anthropogenic activities and presence of sea grasses and mangroves at the 25 sampling sites of the Negombo estuary.

\begin{tabular}{cccccc}
\hline $\begin{array}{c}\text { Sample } \\
\text { site }\end{array}$ & $\begin{array}{c}\text { Presence of } \\
\text { sea grasses }\end{array}$ & $\begin{array}{c}\text { Mresence of } \\
\text { Mangroves }\end{array}$ & $\begin{array}{c}\text { Brush } \\
\text { piles }\end{array}$ & $\begin{array}{c}\text { Encircling } \\
\text { Nets }\end{array}$ & $\begin{array}{c}\text { Disposal of } \\
\text { Sewage }\end{array}$ \\
\hline & & Low (3) & + & - & + \\
1 & - & - & - & - & - \\
2 & - & Low (2) & + & - & + \\
3 & Moderate (4) & Moderate (5) & - & - & - \\
4 & - & - & + & - & - \\
5 & High (7) & - & + & + & - \\
6 & Moderate (6) & - & + & - & + \\
7 & Moderate (4) & - & - & - & + \\
8 & Moderate (4) Moderate (5) & - & - & - \\
9 & - & - & - & + & - \\
10 & - & - & - & + & - \\
11 & - & - & - & + & + \\
12 & - & - & - & - & - \\
13 & High (9) & High (9) & - & - & - \\
14 & High (8) & High (9) & - & - & + \\
15 & - & - & - & - & - \\
16 & High (8) & - & - & - & + \\
17 & - & - & + & + & + \\
18 & - & - & + & + & + \\
19 & High (9) & - & + & + & + \\
20 & Moderate (5) & - & + & + & + \\
21 & High (7) & - & + & - & - \\
22 & - & - & + & + & - \\
23 & High (7) & - & + & + & - \\
24 & - & High (7) & + & - & - \\
25 & - & - & + & - & + \\
\hline
\end{tabular}

Presence of sea grasses and mangroves indicated according to an arbitrary scale (Low: 1-3; Moderate : 4-6; High: 7-9), + Presence, - Absence

The sampling site 25 was excluded from the study of Non-metric MDS and Bray- Curtis similarity, as no macrobenthos were present at this site. When the Bray-Curtis similarity index based on the abundance of macrobenthos is considered, the sampling site 14 , which was located at the freshwater inlet of the Dandugan Oya, was separated from other sampling sites at about the $22 \%$ level of similarity (Fig. 2). This sampling site was clearly separated from other sampling sites in the MDS ordination too, based on the abundance of macrobenthos also (Fig. 3). Of the 7 species of 
macrobenthos found at this sampling site, one species of polychaetes (Order: Errantia) was recorded only at this site. Other polychaetes, which were widely distributed in the estuary such as pilargidiids and some sedentarians, were not found at this site. Further, no gastropods were present at this site although they were abundant at other areas of the estuary. There may have contributed to the separation of site from other sites at $22 \%$ level of similarity in Bray-Curtis similarity analysis and in the MDS ordination. This site was not found to be perturbed by any anthropogenic activity, was rich in seagrasses and was located close to mangrove habitats. However, the salinity at this site was low compared to other sites because of the close location to freshwater inflow (Fig. 1).

Sampling site 19, which was located at the North-East part of the basin segment of the estuary, was separated from other sites at about $24 \%$ level of similarity in the Bray-Curtis analysis based on the abundance of macrobenthos (Fig. 2). It was also clearly separated from other sampling sites in the MDS ordination (Fig. 3).

Sampling site 2, which was located at the sea mouth of the estuary, was separated from other sites at about $26 \%$ level of similarity in the BrayCurtis analysis (Fig. 2). It is also clearly separated from other sampling sites in the MDS ordination (Fig. 3). There were no polychaete, amphipod or isopod species at this sample site. However, 13 species of gastropods and 12 species of bivalves were recorded (Tables 1-3). One species of Acmeid, one species of Littorinid, 3 unidentified species of gastropods and the decapod Eupagurus sp were recorded only at this sample site. Further, of the bivalves, one species of family Limidae, one species of family Mytilidae and two species of family Veneridae were recorded only in this sampling site.

Table 7. Statistically significant values for Spearman Rank Correlation Coefficient $(\mathrm{p}<0.05)$ for permutations of environmental variables in Negombo estuary.

\begin{tabular}{cc}
\hline Correlation Coefficient & Environmental V ariables \\
\hline 0.423 & $2,4,8$ \\
0.420 & 4,8 \\
0.418 & $1,2,4,8$ \\
0.416 & $1,2,4,6,8$ \\
0.415 & $2,4,6,8$ \\
0.410 & $1,4,8$ \\
0.406 & $4,6,8$ \\
0.405 & $1-3,4,8$ \\
0.402 & $1,4,6,8$ \\
0.401 & $2,3,4,8$ \\
\hline
\end{tabular}

V ariables:1- depth, 2- salinity, 3- organic mater content (\%), 4- sand (\%), 5silt (\%), 6- clay (\%), 7- abundance of seagrasses, 8- abundance of mangroves. 


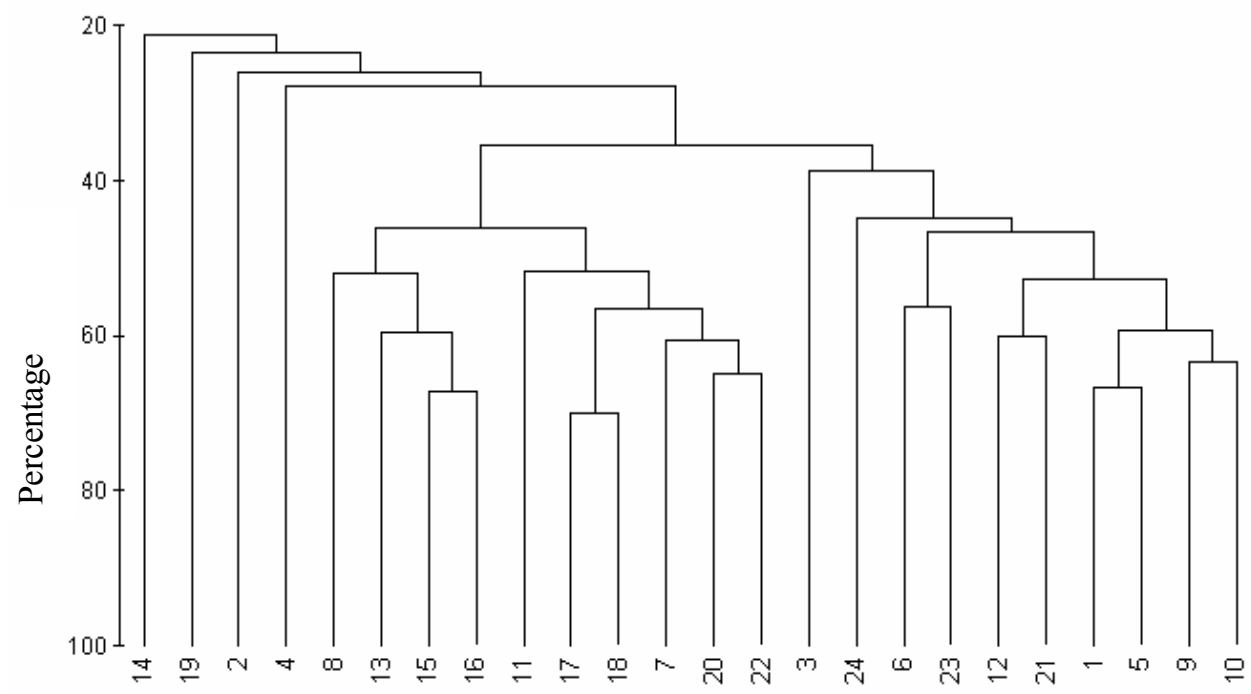

Sample sites

Fig. 2: Dendrogram of the Bray- Curtis similarity index for the sampling sites of Negombo estuary based on the abundance of macrobenthic invertebrates.

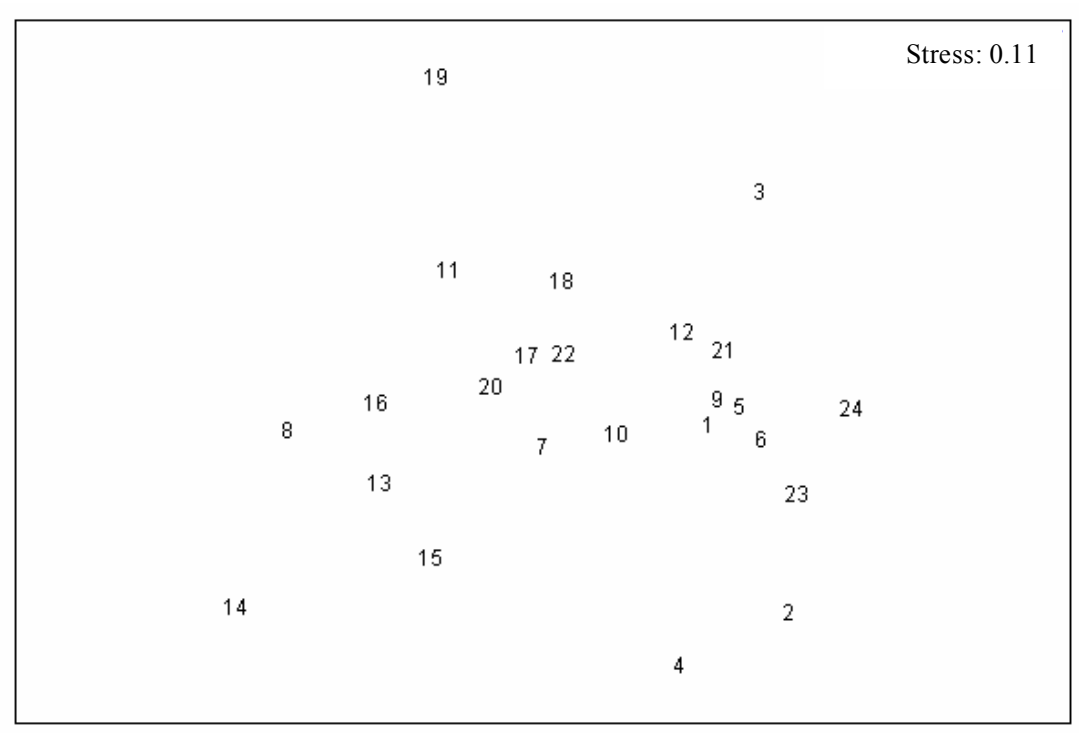

Fig. 3: Two-dimensional MDS ordination of sampling sites of Negombo estuary according to the abundance of macrobenthic invertebrates. 
At about 28\% level of similarity, sampling site 4, which was located at the canal segment of the estuary, was separated from other sampling sites in the Bray-Curtis analysis (Fig. 2). No polychaete species were recorded at this site except for Eunice sp. Further, there were no amphipod or isopod species recorded at this site. Only one species of Assimineid, one species of Hydrobiid, one species of Nassariid and two species of Thiarids were recorded as gastropods at this site. The latter two species were recorded only from this sample site.

Sampling site 3, which was located at the middle part of the canal segment of the estuary, was separated from other sampling sites at about the $38 \%$ level of similarity in the Bray-Curtis similarity analysis (Fig. 2) in the MDS ordination (Fig. 3). No amphipod or isopod species recorded at this sampling site. One species of errantid polychaete was only present at this site.

Spearman rank correlation coefficients for permutations of environmental variables of the BIO-ENV function, which are statistically significant, are given in Table 7 . These results indicate that the combination of salinity, percentage of sand and presence of mangroves mostly affect the diversity and abundance of macrobenthos. The depth, $\%$ clay and $\%$ organic matter content also significantly affect the abundance and diversity of macrobenthos in the Negombo estuary.

\section{Discussion}

The composition and abundance of benthic organisms are closely related to the water quality of aquatic environments (Mackenthum, 1966; Costa et al. 1997; Weerasundara et al. 1999; 2000; Pathiratne \& Weerasundara 2004) and therefore, benthic organisms are considered to be good indicators of the past and present conditions of water (Bruse et al. 1975, Gamlath \& Wijeyaratne 1997). The presence of unusually large populations of benthic organisms as well as absence of some others can be used as indicators of pollution in water bodies (Hart \& Fuller 1974; Lobe \& Space 1993).

The lowest species diversity and species richness were recorded in the sampling site 14 . The rapid flow rate at this site may have contributed to low species diversity and species richness. Most of the species recorded in other parts of the estuary were not found at the sampling site 19 . The abundance of most of the macrobenthic species that were present was also lower than their abundance in other parts. These factors may have contributed for the separation of sampling site 19 at about $25 \%$ level of similarity in the Bray-Curtis similarity analysis and in the MDS ordination (Fig. 3). Use of fishing gear such as encircling nets and brush piles was noted in this area and the sewage from nearby human dwellings may have contaminated water at this site. These factors may have contributed to the low abundance of macrobenthos, at this sampling site. Low organic matter and high sand contents, together with high salinity may have contributed to the variation in 
the macrobenthic community at sampling site 2 from that of other sampling sites. The substrates with high organic matter content are preferred by sedentarian polychaetes and amphipods. Therefore high sand content at the sampling site 2 may have significantly contributed for the absence of sedentarian polychaetes and amphipods at this site. Absence of polychaetes and amphipods at sampling site 4 also may be due to high sand and low organic matter contents. Perkins (1974) also reported similar trends. This sampling site was also located near human dwellings and this may have also contributed for the difference in the macrobenthic community structure at this site from that of other sites.

The low abundance and/ or absence of some common polychaetes, gastropods and some crustaceans may be the reason for this separation of sampling site 3 from other sampling sites at $38 \%$ level of similarity. This sampling site is located close to of an effluent discharge point of a shrimp farm. Effluents from shrimp farm may have contributed for this difference in the community structure of benthic macrofauna at this site from that of other sites.

The area of sampling site 25 is highly polluted due to sewage discharged from the households. Further, the circulation of water at this part of the estuary was also observed to be very poor. Benthic organisms are reported to be rare in heavily polluted waters (Pearson \& Rosenberg 1978). Therefore, the water in this part may be highly polluted resulting in the absence of benthic macrofauna.

The results indicate the species richness of gastropods and bivalves is high and that of amphipods and polychaetes is low at the sampling sites located at the canal segment. Perkins (1974) has reported that the amphipods and polychaetes are an important constituent of macrobenthic communities of the inner areas of estuaries, which are associated with the finer sediments. The sampling sites at the canal segment are rich with sand, and therefore associated with coarser sediments than other sampling sites. Hence, this may be the reason for low abundance of amphipods and polychaetes at these sampling sites. The Spearman rank correlation coefficients given in Table 7 also indicates that $\%$ sand content in the estuary is a significant factor that affect the diversity of benthic fauna.

Mollusks are found to be abundant in the areas with dense vegetation (Hart \& Fuller 1974). However, in the present study, high abundance of mollusks was recorded at sample site 2, where there was no vegetation. Therefore, it appears that vegetation cover cannot be considered as a factor contributing to abundance of all species of mollusks in general.

Cerithidea cingulata was recorded to be abundant on the mud flats adjoining the mangroves (Pinto 1986). However, in the present study Cerithidea cingulata was not recorded in sampling sites that were close to mangroves (sample sites 4, 13, 14 and 24) but was found to be abundant in other sampling sites including those which are not close to mangrove areas. Nevertheless, the Spearman rank correlation coefficients given in Table 7 
indicate that the mangroves are a significant factor, which contributes to community structure of benthic macrobenthos of this estuary as a whole.

Use of some types of fishing gear such as encircling nets has been reported to affect the macrobenthic community structure by destroying the seagrass beds (Anon. 1994). In the present study, seagrass beds were not found in some of the sampling sites, where the encircling nets are used. They include sampling site 9, 10,11, 17, 18 and 22. However in some sampling sites where encircling nets are operated, such as sites 6, 19, 20 and 23 seagrass coverage is high or moderate. Therefore it appears that use of encircling nets is not the only factor that affects the abundance of seagrasses. However, when the abundance of seagrasses is low the species richness of macrobenthos was also found to be low.

Perkins (1974) has reported that benthic community structure depends on environmental factors such as salinity, temperature, dissolved oxygen content, depth, organic mater content, soil texture and size of sediment particles. During the present study the temperature and dissolved oxygen content were not measured because the temperature was reported as more or less constant and the dissolved oxygen content varies within the same range throughout the estuary (Silva 1981). The Spearman's rank correlation coefficients calculated for permutations of environmental variables indicate that in Negombo estuary, the environmental variables that significantly affect the community structure of macrobenthos are the depth, salinity, organic matter content, \% sand and clay contents in the sediments and the abundance of mangroves.

The results of the present study indicate that the biodiversity of macrobenthos in the Negombo estuary is very high. Further, some of the species recorded in the present study, such as some amphipods and polychaetes have not been reported in Sri Lanka in previous studies. Most of the species recorded in the present study could not be identified beyond the family level. Therefore it is necessary to carry out a detail taxonomic study of the benthic fauna of the Negombo estuary relating the macrobenthic community structure to water quality parameters and resource use patterns.

\section{Acknowledgement}

The authors are thankful to Dr. (Mrs.) S.C. Jayamanne, former Director General of the National Aquatic Resources Research and Development Agency, Sri Lanka for providing facilities to identify macrobenthos. 


\section{References}

Anonymous, 1994.

Conservation Management Plan: Muthurajawela Marsh \& Negombo Lagoon, Wetland Conservation Project, Central Environmental Authority, Sri Lanka and Euroconsult, Netherlands, 129 p.

Bouguenec, V. \& N. Giani 1989.

Aquatic Oligochaeta as prey for invertebrates and vertebrates: A review. Acta Oecologica 10(3): 177-196.

Brady, N.C. \& R.R. Weil 1999.

The Nature and Properties of Soils. (Twelfth edition) Prientice-Hall, Inc., New Jersey, $137 \mathrm{p}$.

Bray, J.R. \& J.T. Curtis 1957.

An ordination of the upland forest communities of Southern Wisconsin. Ecological Monographs 27: 325-349.

Bruse, C.C., W.D. Craing \& C.A. Robert 1975.

A synoptic study of the limnology of lake Thonotosassa, Florida: Part 1. Effects of primary treated sewage and citrus wastes. Hydrobiologia 46: 301-345.

Clarke, K.R. \& R.M. Warwick 2001.

Changes in Marine Communities: An Approach to Statistical Analysis and Interpretation ( $2^{\text {nd }}$ Edition $)$, Primer-E Ltd, $91 \mathrm{p}$.

Costa, H.H., G.A. W eerasundara \& A. Pathiratne 1997.

Species composition, abundance and distribution of Aquatic

Oligochaetes in Colombo (Beira) Lake, Sri Lanka. Sri Lanka Journal of Aquatic Sciences 2: 69-80.

Elliott, M. \& C.J.L. Taylor 1989.

The Production Ecology of the Subtidal Benthos of the Forth Estuary, Scotland. In: Topics in Marine Biology. (S.D Ros ed.), pp 531-541.

Fauchald, K. 1977.

The Polychaete W orms: Definitions and Keys to the Orders, Families and Genera. Natural History Museum of Los Angeles County, 173 p.

Fernando, C.H. 1990.

The Freshwater Fauna and Fisheries of Sri Lanka, Natural Resources, Energy and Science Authority of Sri Lanka, $276 \mathrm{p}$.

Gamlath, G.A.R.K. \& M.J.S. Wijeyaratne 1997.

Indicator organisms of environmental conditions in a lotic waterbody in Sri Lanka. Sri Lanka Journal of Aquatic Sciences 2: 121-129.

Hart, Jr. C.W . \& S.L.H. Fuller 1974.

Pollution Ecology of Freshwater Invertebrates, Academic Press, London, $371 \mathrm{p}$.

Kirthisinghe, P. 1978.

Seashells of Sri Lanka, Charles E. Tuttle Company Inc. of Rutland, V ermant \& Tokyo, Japan, $202 \mathrm{p}$.

Krebs, C.J. 1999. 
Ecological Methodology (2 $2^{\text {d }}$ edition), Addison-Welsey Educational Publishers Inc., USA, 620 p.

Lobe, L.S., \& A. Space 1993.

Biological Monitoring of Aquatic Systems, Lewis Publishers, London, $187 \mathrm{p}$.

Mackenthum, K.M. 1966.

Biological evaluation of polluted streams. Journal of W ater Pollution

Control Federation 38: 241-247.

Needham, J.G. \& P.R. Needham 1962.

A Guide to the Study of Fresh Water Biology ('th edition), Holden-

Day Inc., San Francisco, 108 p.

Pathiratne, A. \& G.A. Weerasundara 2004.

Bioassessment of selected inland water bodies in Sri Lanka using benthic oligochaetes with consideration of temporal variation. Internationale Revue derges Hydrobiologie 89: 305-316.

Pearson, T.H. \& R. Rosenberg 1978.

Macrobenthic succession in relation to organic enrichment and pollution of the marine environment. Annual Review of Oceanography and Marine Biology 16: 229-311.

Perkins, E.J. 1974.

The Biology of Estuaries and Coastal waters, Academic Press Inc., London, $678 \mathrm{p}$.

Pinto, L. 1986.

Mangroves of Sri Lanka. Natural Resources Energy and Science

Authority of Sri Lanka, 54 p.

Popchenko, V.I. 1971.

Consumption of Oligochaeta by fishes and invertebrates. Journal of Ichthyology 11: 75-80.

Robertson, M.R., D.C. Moore \& S. Ekaratne 1997.

Taxonomy of marine Polychaetes, Amphipodes and Isopodes. Marine Laboratory, Aberdeen, Scotland/ University of Colombo, Sri Lanka, $70 \mathrm{p}$.

Samarakoon, J. \& H. van Zon 1991.

Environmental Profile of Muthurajawela and Negombo lagoon,

Greater Colombo Economic Commission, Sri Lanka and Euroconsult, the Netherlands, $173 \mathrm{p}$.

Silva, E.I.L. 1981.

Contribution in the Biology and Fishery of Grey Mullet, Mugil cephalus L., in the Negombo Lagoon with Notes on Hydrography. M.Phil Thesis, University of Kelaniya, Sri Lanka.

Sutherland, W.J. 1997.

Ecological Census Techniques (A hand book), Cambridge University

Press, $336 \mathrm{p}$.

W eerasundara, G.A., A. Pathiratne \& H.H. Costa 1999. 
Species composition and abundance of aquatic Oligochaetes in Ihalagama reservoir, a shallow perennial minor reservoir in Sri Lanka: Sri Lanka Journal of Aquatic Sciences 4: 61-67.

W eerasundara, G.A., A. Pathiratne \& H.H. Costa 2000.

Species composition and abundance of littoral oligochaete fauna in Lunuwila reservoir, Sri Lanka. Internationale Revue derges Hydrobiologie 85: 223-230.

Williams, I. 2001.

Environmental Chemistry, A Modular Approach. John Wiley \& Sons, Ltd, England, 139-146 p.

Zar, J.H. 1984.

Biostatistical Analysis (2 $2^{\text {nd }}$ edition), Prentice-Hall Inc., Englewood.

Cliff, New Jersey, 718 p. 
